\title{
MODELLING GROSS PRIMARY PRODUCTION OF TROPICAL FOREST BY REMOTE SENSING
}

\author{
VELASQUE, Maísa Caldas Souza - maisacaldas@fisica.ufmt.br \\ Universidade Federal do Mato Grosso/UFMT \\ BIUDES, Marcelo Sacardi - marcelo@fisica.ufmt.br \\ Universidade Federal do Mato Grosso/UFMT
MACHADO, Nadja Gomes - nadja.machado@blv.ifmt.edu.br Instituto Federal do Mato Grosso/IFMT
DANELICHEN, Victor Hugo de Morais- danelichen@fisica.ufmt.br Universidade de Cuiabá/UNIC
VOURLITIS, Geoge Louis - georgev@csusm.edu California State University

NOGUEIRA, José de Souza - nogueira@ufmt.br Universidade Federal do Mato Grosso/UFMT

\begin{abstract}
The application of remote sensing has provided an opportunity to improve the estimation of gross primary production (GPP) on a regional scale. Several models to estimate GPP of homogeneous ecosystems, such as agricultural areas, entirely based on remote sensing data exist, but models to describe more heterogeneous areas are less common. Thus, the aim of the study was to evaluate the GPP estimated by different remote sensing methods in an Amazon-Cerrado transition forest in Mato Grosso, using MODIS spectral data. Two models, known as the temperature and greenness model (TG) and the vegetation index (VI) model, were used to estimate seasonal and interannual variations in GPP from June 2005 to May 2008. Our results indicated that the TG and VI models were incapable of reproducing the seasonal variation in GPP, because the lack of correlation between vegetation indices and the GPP measured from tower-based eddy covariance $\left(\mathrm{GPP}_{\mathrm{EC}}\right)$. Furthermore, the time series of the enhanced vegetation index (EVI) was delayed by 2 months with $\mathrm{GPP}_{\mathrm{EC}}$. The results presented in this paper highlight some of the complexities in validating satellite products. Further study over a variety of Brazilian forests is needed to quantitatively assess the TG and VI and other methods to improve their accuracy.
\end{abstract}

Keywords: net $\mathrm{CO}_{2}$ exchange, transitional tropical forest, light use efficiency, MODIS.

\section{MODELAGEM DA PRODUÇÃO PRIMÁRIA BRUTA DE FLORESTA TROPICAL POR SENSORIAMENTO REMOTO}

RESUMO: A aplicação do sensoriamento remoto tem possibilitado a oportunidade para melhorar a estimativa da produção primária bruta (GPP) em escala regional. Existem vários modelos para estimar GPP de ecossistemas homogêneos, tais como áreas agrícolas, inteiramente baseados em dados de sensoriamento remoto, mas modelos para descrever áreas heterogêneas são menos comuns. Dessa forma, o objetivo do estudo foi avaliar a GPP estimada por diferentes métodos de sensoriamento remoto em uma floresta de transição do Amazonas-Cerrado em Mato Grosso, utilizando-se os dados espectrais do sensor MODIS. Para estimar as variações sazonais e interanuais do GPP foram utilizados dois modelos, conhecidos como modelo de temperatura e verde (TG) e o índice de vegetação (VI) entre junho de 2005 e maio de 2008. Os resultados indicaram que os modelos TG e VI não conseguiram reproduzir a variação sazonal do GPP, devido à falta de correlação entre os índices de vegetação e o GPP medido pelo método de correlações de vórtices turbulentos ( $\left.\mathrm{GPP}_{\mathrm{EC}}\right)$. Além disso, a série temporal do índice de 
vegetação melhorado (EVI) foi atrasada em 2 meses em relação ao GPPEC. Os resultados apresentados neste artigo destacam algumas das complexidades na validação de produtos de satélite. Futuros estudos sobre várias florestas brasileiras são necessários para avaliar os modelos TG e VI e outros para melhorar sua precisão.

PALAVRAS-CHAVES: troca líquida de $\mathrm{CO}_{2}$, floresta tropical de transição, eficiência do uso leve, MODIS.

\section{MODÉLISATION DE LA PRODUCTION PRIMAIRE BRUTE DE FORÊT TROPICALE PAR TÉLÉDÉTECTION}

RESUME: L'application de la télédétection a permis d'améliorer l'estimation de la production primaire brute (GPP) à l'échelle régionale. Plusieurs modèles d'estimation des GPP d'écosystèmes homogènes, comme les zones agricoles, sont entièrement basés sur des données de télédétection, mais les modèles pour décrire des zones plus hétérogènes sont moins fréquents. Le but de l'étude était donc d'évaluer le GPP estimé par différentes méthodes de télédétection dans une forêt de transition de I'Amazonie-Cerrado au Mato Grosso, en utilisant les données spectrales MODIS. Deux modèles, connus sous le nom de modèle de température et de verdure (TG) et le modèle de l'indice de végétation (VI), ont été utilisés pour estimer les variations saisonnières et interannuelles des GPP entre juin 2005 et mai 2008. Nos résultats indiquent que les modèles TG et VI n'ont pas été en mesure de reproduire la variation saisonnière des GPP, en raison de l'absence de corrélation entre les indices de végétation et les GPP mesurés à partir de la covariance par tourbillons en tour (GPP $\mathrm{EC}_{\mathrm{C}}$ ). De plus, la série chronologique de l'indice de végétation amélioré (EVI) a été retardée de 2 mois avec GPPEC. Les résultats présentés dans ce document mettent en évidence certaines des complexités de la validation des produits satellites. Des études complémentaires sur une variété de forêts brésiliennes sont nécessaires pour évaluer quantitativement TG et VI et d'autres méthodes pour améliorer leur précision..

MOTS CLÉS: échange net de $\mathrm{CO}_{2}$, forêt tropicale de transition, utilisation légère, MODIS

\section{INTRODUCTION}

Tropical forests have received special attention in recent years due to its high biodiversity and terrestrial carbon (C) stocks (SAATCHI et al., 2011). Tropical rainforests sequester more carbon than any other biome or land cover class (AHLSTRÖM et al., 2015). However, rainforests have also been changed due to deforestation and human activity, which is altering the carbon cycle and microclimate of the region (VOURLITIS et al., 2011; BIUDES et al., 2014a). These changes modify the rate of carbon converted to biomass through photosynthesis, which on a canopy scale can be estimated as gross primary production (GPP) (XIAO et al., 2004).

Despite the importance of studying the carbon cycle, there is a discrepancy in the estimates of GPP from different ecosystems and from different models, which impairs the understanding of the global estimate of carbon exchanged between the surface and the atmosphere (WU et al., 2011). Ecosystem $\mathrm{C}$ exchange is now routinely performed by tower-based eddy covariance (EC), but these measurements only represent one point on the Earth's surface. Thus, the estimation of GPP over regional and global scales using point measurements from EC is a complex task due to the large spatial variability of terrestrial ecosystems (SOUZA et al., 2014).

The application of remote sensing provides an opportunity to improve the estimation of GPP on a regional scale (SILVA et al., 2013), particularly in regions where there is no meteorological data. Many of these remote sensing GPP 
models are developed from the Light Use Efficiency (LUE), which varies spatially and temporally due to its dependence on the vegetation type and weather conditions (TURNER et al., 2006). Therefore, when considering the constant LUE, as proposed by most models, many errors and limitations are introduced in the estimation of GPP (WU et al., 2010). Estimating LUE from remote sensing permits improve estimates of GPP in regions with heterogeneous coverage.

One representative of such models is the MODIS (Moderate Resolution Imaging Spectroradiometer) GPP product (MOD17) (RUNNING et al., 2004), which express the LUE by two scaling factors representing influences from air temperature and vapor pressure deficit. Similar logic is used in the Vegetation Photosynthesis model (VPM) (XIAO et al., 2004). However, many studies questioned the MODIS GPP product and VPM model that requires meteorological inputs are often not available as sufficiently detailed temporal and spatial scales (SIMS et al., 2008; WU et al., 2010). In addition, some studies have shown that GPP values estimated by MOD17 are lower than those measured in tropical rainforest (SOUZA et al., 2014) and the VPM model requires local calibration (BIUDES et al., 2014b), which makes it difficult have a general model to estimate the spatio-temporal variation of the GPP.

Some studies have shown a positive relationship between vegetation indices as EVI (Enhanced Vegetation Index) and NDVI (Normalized Difference Vegetation Index) and LUE (JENKINS et al., 2007; NAKAJI et al., 2007; DROLET et al., 2008; CHENG et al., 2009). For this reason, models to estimate GPP entirely based on remote sensing data have become increasingly common, such as the Temperature Greenness Model (TG) (SIMS et al., 2008) and the Vegetation Index Model (VI) (WU et al., 2010).

Most GPP estimation models have been developed for agricultural areas (WU et al., 2009; WANG et al., 2010; ROBERTSON et al., 2015). However, the TG and VI models have not been tested in tropical ecosystems. Thus, the aim of the study was to evaluate the GPP estimated by different remote sensing methods in an Amazon-Cerrado transition forest in Mato Grosso, using MODIS spectral data. We hypothesize that the estimates of GPP by TG and VI models will provide a good fit with GPP measured by EC because the LUE has a good relationship with vegetation indices.

\section{MATERIALS AND METHODS}

\subsection{STUDY AREA DESCRIPTION}

This study was conducted in an area of transitional forest in Mato Grosso from June 2005 to May 2008 (Figure 1). The site was a dense semi-deciduous forest in the transition between the Amazon and the Cerrado, on the Fazenda

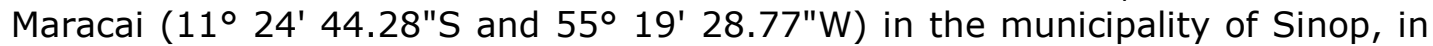
the northern state of Mato Grosso, Brazil. The canopy height is $22-25 \mathrm{~m}$ and leaf area index (LAI) ranges from $7.0 \mathrm{~m}^{2} \mathrm{~m}^{-2}$ in the dry season to approximately 8.0 $\mathrm{m}^{2} \mathrm{~m}^{-2}$ in the wet season (BIUDES et al., 2014a). The vegetation is dominated by trees of the species Brosimum lactescens, Quaela paraenses and Tovomita schomburkii. The average temperature over 30 years was around $24^{\circ} \mathrm{C}$ with little seasonal variation and precipitation was $2000 \mathrm{~mm}$ per year, with 4-5 months of dry season (May to September). The soil is a Quartzarenic Neosol 
characterized by the sandy texture ( $84 \%$ sand, $4 \%$ silt and $12 \%$ clay), at $50 \mathrm{~cm}$ depth of soil (PRIANTE-FILHO et al., 2014).
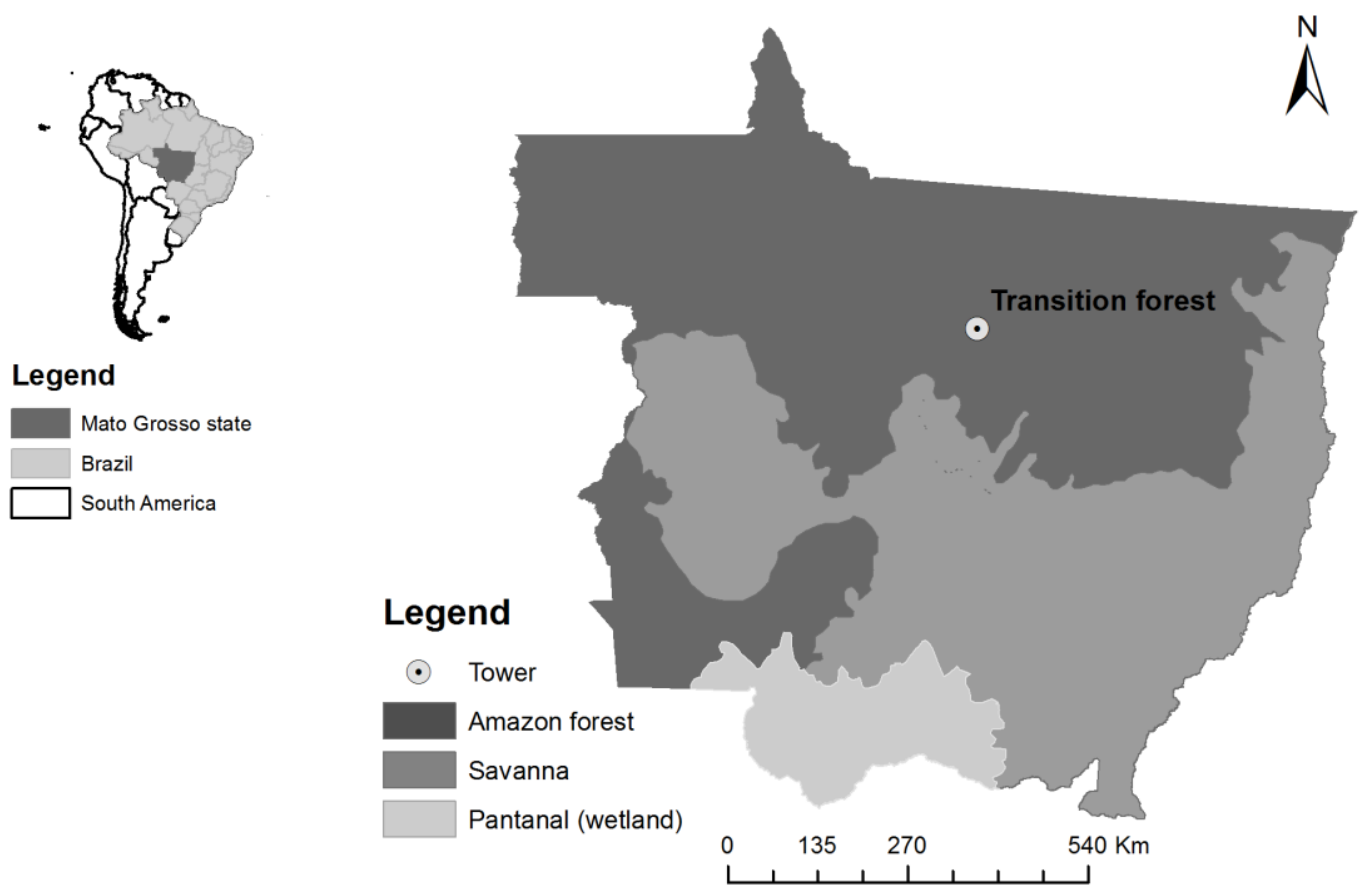

Figure 1 - Location of the micrometeorological tower in the Amazon-Cerrado transitional forest Mato Grosso, Brazil.

\subsection{EDDY COVARIANCE AND MICROMETEOROLOGICAL MEASUREMENTS}

Net ecosystem exchange (NEE) and energy balance were measured using the eddy covariance method (VOURLITIS et al., 2011). Eddy covariance sensors were mounted on a walk-up tower at a height of $42 \mathrm{~m}$ above ground level. The eddy covariance system utilized a three-dimensional sonic anemometerthermometer (CSAT-3, Campbell Scientific, Inc., Logan, UT, USA) to measure the mean and fluctuating quantities of wind speed and temperature and an open-path infrared gas analyzer (LI-7500, LI-COR, Inc. Lincoln, NE, USA) to measure the mean and fluctuating quantities of $\mathrm{CO}_{2}$ molar density. The infrared gas analyzer was installed approximately $5 \mathrm{~cm}$ downwind of the sonic anemometer to minimize sensor separation and at an angle of $20^{\circ}$ to allow moisture from rain or dew to rapidly roll-off the light-source window. Raw (10 $\mathrm{Hz}$ ) and average $\mathrm{CO}_{2}$ fluxes data were stored and processed using a solid-state data logger (CR1000, Campbell Scientific, Inc., Logan, UT, USA).

Canopy $\mathrm{CO}_{2}$ storage was determined by quantifying the rate of change of the $\mathrm{CO}_{2}$ concentration of the air column between the ground surface and the eddy covariance sensors (VOURLITIS et al., 2011). Air samples were drawn at $1,4,12,20$, and $28 \mathrm{~m}$ above ground level using a diaphragm pump and solenoid switching system, and the vertical $\mathrm{CO}_{2}$ concentration profile was measured using a closed-path $\mathrm{CO}_{2}$ analyzer (LI-820, LI-COR, Inc., Lincoln, NE, USA). The gradient measurement system was operational for $30 \%$ of all observations, and during system failure canopy $\mathrm{CO}_{2}$ storage was quantified from 
the $\mathrm{CO}_{2}$ concentration measurements made at the top of the tower, which did not differ from those derived from the gradient measurements (VOURLITIS et al., 2011).

Photosynthetically active radiation (PAR) was measured above each canopy using a quantum sensor (LI-190SB, LI-COR, Lincoln, NE, USA). The air temperature and relative humidity were measured at the top of each tower using a thermohygrometer (HMP-45 C, Vaisala Inc., Helsinki, Finland). Micrometeorological sensor output was measured every $30 \mathrm{~s}$ using a solid-state data logger (CR1000, Campbell Scientific, Inc., Logan, UT, USA) and data were averaged over half-hourly intervals. Precipitation data were obtained daily from a manual rainfall gauge located $5 \mathrm{~km}$ southeast of the eddy flux tower because data obtained at the eddy flux tower was periodically unavailable and/or unreliable (VOURLITIS et al., 2011).

\section{3. $\mathrm{CO}_{2}$ FLUX CALCULATION AND DATA TREATMENT}

Carbon dioxide and energy fluxes were obtained by calculating the covariance between the fluctuations in vertical wind speed and fluctuations in virtual temperature, $\mathrm{H}_{2} \mathrm{O}$ vapor, or $\mathrm{CO}_{2}$ molar density following a coordinate rotation of the wind vectors (McMILLEN et al., 1988) and averaged over 30 minute time periods. Eddy $\mathrm{CO}_{2}$ flux derived from the open-path gas analyzer was corrected for simultaneous fluctuations in heat and $\mathrm{H}_{2} \mathrm{O}$ vapor while eddy $\mathrm{H}_{2} \mathrm{O}$ vapor flux was corrected for fluctuations in heat flux (WEBB et al., 1980).

NEE was calculated as the sum of eddy $\mathrm{CO}_{2}$ flux and canopy $\mathrm{CO}_{2}$ storage. NEE data were screened for quality following guidelines established by Ameriflux and Anthoni et al. (1999). Data were rejected when (1) eddy covariance sensors failed or were down because of calibration and system maintenance; (2) warming flags were generated by the system software indicating measurement and/or processing errors; (3) spikes in sonic and/or infrared gas analyzer data were excessive such as during heavy rainfall events; (4) abrupt changes in wind speed caused nonstationary conditions; and (5) eddy flux data were outside physically and/or biologically meaningful ranges (VOURLITIS et al., 2011).

Gross primary production (GPP) was estimated by Equation (1) following methods described by Wohlfahrt et al. (2005),

$$
G P P=N E E-R_{\text {eco }}
$$

where $N E E$ is the daytime (PAR $>5 \mu \mathrm{mol}$ photons $\mathrm{m}^{-2} \mathrm{~s}^{-1}$ ) net ecosystem $\mathrm{CO}_{2}$ exchange measured from eddy covariance and $R_{\text {eco }}$ is an average rate of daytime ecosystem respiration. Estimates of $\varepsilon_{o}$, daytime $R_{\text {eco }}$ and GPP were derived using a Michaelis-Menton type function (RUIMY et al., 1995; WOHLFAHRT et al., 2005) by Equation (2) over 8-day intervals (to be consistent with MODIS data acquisition),

$$
N E E=\frac{\varepsilon_{o} P A R F_{G P P, s a t}}{\varepsilon_{o} P A R+F_{G P, s a t}}-R_{e c o}
$$

where $\varepsilon_{0}$ is the maximum apparent quantum yield ( $\mu \mathrm{mol} \mathrm{CO}_{2} \mu \mathrm{mol}$ photons ${ }^{-1}$ ), PAR is the measured average 30-minute average photosynthetically active radiation ( $\mu \mathrm{mol}$ photons $\left.\mathrm{m}^{-2} \mathrm{~s}^{-1}\right), F_{G P P, s a t}$ is the light-saturated rate of GPP ( $\mu \mathrm{mol}$ 
$\mathrm{CO}_{2} \mathrm{~m}^{-2} \mathrm{~s}^{-1}$ ), and $R_{e c o}$ is daytime respiration rate that is estimated as the intercept of Equation (2) where PAR $=0 \mu \mathrm{mol} \mathrm{m} \mathrm{m}^{-2} \mathrm{~s}^{-1}$. Estimates of $R_{\text {eco }}$ derived using these methods compare well to those estimated from nighttime data (FALGE et al., 2001), and minimize problems associated with nighttime flux loss from low turbulence and errors in objectively selecting a turbulence (i.e., frictional velocity) threshold that excludes data measured under inadequate turbulence (WOHLFAHRT et al., 2005)..

\subsection{SATELLITE IMAGERY AND VEGETATION INDICES}

We downloaded the 8-days composite land surface reflectance data (MOD09A1) from the EROS Data Active Archive Center (EDC Daac, http://daac.ornl.gov/cgi-

bin/MODIS/GLBVIZ_1_Glb/modis_subset_order_global_col5.pl) based on the geo-location information (latitude and longitude) of eddy covariance flux tower. The MOD09A1 datasets include seven spectral bands, at a spatial resolution of $500 \mathrm{~m}$, corrected for the effects of atmospheric gases, aerosols, and thin cirrus clouds and include a quality assurance of each pixel (QA) (VERMOTE and KOTCHENOVA, 2008). Land surface reflectance values were averaged for the nine pixels covering and surrounding each eddy flux towers, and only values of clear-sky land surface reflectance were used, i.e., pixels with highest quality assurance $(\mathrm{QA})$. Land surface reflectance values from blue $\left(\rho_{\text {blue }}\right)$, red $\left(\rho_{\text {red }}\right)$ and near-infrared $\left(\rho_{\text {nir }}\right)$ were used to calculate the Enhanced Vegetation Index (EVI, Equation 3) (HUETE et al., 1997) and Normalized Difference Vegetation Index (NDVI, Equation 4).

$$
\begin{aligned}
E V I & =2.5 \frac{\rho_{\text {nir }}-\rho_{\text {red }}}{\rho_{\text {nir }}+6 \rho_{\text {blue }}-7.5 \rho_{\text {red }}+1}, \\
N D V I & =\frac{\rho_{\text {nir }}-\rho_{\text {red }}}{\rho_{\text {nir }}+\rho_{\text {red }}},
\end{aligned}
$$

The product provides MOD11A2 surface temperature data (LST) and emissivity, which are derived from the application of split window algorithm and stored on a $1 \mathrm{~km}$ Sinusoidal grid as the average values of clear-sky LSTs during an 8days period. The emissivity in the bands 31 and 32 are estimated from types of soil cover, water vapor in the atmospheric column and the lower surface temperature, which is separated into sub-bands for optimal recovery (WU et al., 2010). Only values of clear-sky LSTs with highest quality assurance (QA) were used.

\subsection{ESTIMATION MODELS OF GPP BY REMOTE SENSING}

Two models for estimating GPP by orbital sensor data were used in this study. Both models combine remote sensing products to represent the variation of the Light Use Efficiency (LUE). The Temperature and Greenness model (TG) is based exclusively on remote sensing product data and the Vegetation Index model (VI) relates surface data such as photosynthetically active radiation and remote sensing products data.

The TG developed by Sims et al. (2008) was based on EVI (Enhanced Vegetation Index) and LST (Land Surface Temperature), both derived from MODIS products. The TG model (Equation 5) is a combination of a scalar 
function of LST (Equation 6) and EVI (Equation 7) due to an important correlation between LST, vapor pressure deficit (VPD) and photosynthetically active radiation (PAR) (WU et al. 2011).

$$
G P P=m \times \text { LSTesc } x \text { EVIesc, }
$$

where LSTesc and EVIesc is the scalar function of LST (Equation 6) and EVI (Equation 7) and $m$ is a scalar $\left(\mathrm{molC} \mathrm{m} \mathrm{m}^{-2} \mathrm{~d}^{-1}\right.$ ) as a function of annual mean nighttime LST $\left(L S T_{a n}\right)$ (Equation 8).

$$
\begin{aligned}
& \text { LSTesc }=\min \left[\left(\frac{L S T}{30}\right) ;(2.5-(0.05 L S T))\right] \\
& \text { EVIesc }=E V I-0.1 \\
& m=2.00+0.98 x L S T_{a n}
\end{aligned}
$$

where LSTesc is defined as the minimum of two linear equations. This results in a maximum value of LSTesc $=1.0$ for LST $=30^{\circ} \mathrm{C}$ and minimum values when LST $<=0^{\circ} \mathrm{C}$ or LST $>=50^{\circ} \mathrm{C}$ (SIMS et al., 2008; WU et al., 2010). Previous study by Sims et al. (2008) show that GPP decreases to zero when the EVI is proximately 0.1 .

The Vegetation Index model (VI) was proposed by Wu et al. (2010) and calculates GPP by multiplying PAR and two vegetation indices (VI) (Equation 9). This model has been proposed based on various literature which demonstrate that the vegetation indices represent both Light Use Efficiency (LUE) and Fraction of Photosynthetically Active Radiation (FPAR), which have the same biophysical characteristics (GITELSON et al., 2006; INOUE et al., 2008; WU et al., 2009).

$$
G P P=P A R x V I x V I,
$$

\subsection{DATA ANALYSIS}

Monthly, seasonal and annual average with $\pm 95 \%$ confidence interval of EVI, NDVI, LST and micrometeorological variables were calculated by bootstrapping 1000 iterations of random resampling with replacement (EFRON and TIBSHIRANI, 1994) using the Package Boot to $\mathrm{R}$ software (CANTY and RIPLEY, 2015). Spearman correlation matrix was calculated with volumetric soil water content (VSWC) and vegetation indices.

Willmott's index " $d$ " (Eq. 10), the root mean square error " RMSE" (Eq. 11), the mean absolute error "MAE" (Eq. 12) and the Pearson correlation were used to evaluate the performance of the GPP estimated by TG and VI models

$$
\begin{gathered}
d=1-\left[\frac{\sum\left(P_{i}-O_{i}\right)^{2}}{\sum\left(\left|P_{i}-O\right|+\left|O_{i}-O\right|\right)^{2}}\right] \\
R M S E=\sqrt{\frac{\sum\left(P_{i}-O_{i}\right)^{2}}{n}} \\
M A E=\sum \frac{\left|P_{i}-O_{i}\right|}{n}
\end{gathered}
$$

values and $n$ is the number of observations. Willmott's statistic relates the performance of an estimation procedure based on the distance between 
estimated and observed values, with values ranging from zero (no agreement) to 1 (perfect agreement). The RMSE indicates how the model fails to estimate the variability in the measurements around the mean and measures the change in the estimated values around the measured values (WILLMOTT and MATSSURA, 2005). The lowest threshold of RMSE is 0 , which means there is complete agreement between the model estimates and measurements. The MAE indicates the distance (deviation) mean absolute values estimated from the values measured. Ideally, the values of the $M A E$, and the RMSE were close to zero (WILLMOTT and MATSSURA, 2005).

\section{RESULTS AND DISCUSSION}

\subsection{ANALYSIS OF METEOROLOGICAL DATA AND MEASURED GPP}

Precipitation was seasonal, with $96 \%$ of the total annual occurring during the wet season and the rest between May and September (Table 1; Fig. 2a), which is consistent with the 4-5 months of drought characteristic of the region (BIUDES et al., 2015). The highest precipitation values occurred in December in each year of the study (Fig. 2a), which is typical for this region as December is historically the wettest month (VOURLITIS et al., 2014).

PAR was $20 \%$ higher in the dry season (Table 1 ), with peaks between June and July (Figure 2b) due to the higher number of days of clear skies and lower cloudiness. There was no significant seasonal variation in the air temperature (Table 1 ). The average air temperature was $24.8^{\circ} \mathrm{C}$, below than $26.4^{\circ} \mathrm{C}$ found by Vilani et al. (2006) from 2001 to 2003 . The highest temperature was in 2005 (Table 1), and during the following years the air temperature decreased slightly $\left(2^{\circ} \mathrm{C}\right)$ from 2005 to 2008 . There was an intense drought throughout the region of the Amazon basin in 2005 (MARENGO et al., 2008), what deserves special attention because the increase in air temperature causes an increase in the vapor pressure deficit (VPD), which can decrease in stomatal conductance and net photosynthetic rate (WU et al., 2010). The air temperature was inversely correlated with relative humidity $(r=-0.72 ; p$-value $<0.01)$ and positively correlated with the VPD $(r=0.81 ; p$-value $<0.001)$. 
Table 1 - Total annual, dry season (May-September) and wet season (October-April) precipitation (Ppt, $\mathrm{mm})$ and mean ( $\pm 95 \%$ confidence interval) air temperature (Temp., ${ }^{\circ} \mathrm{C}$ ), photosynthetically active radiation (PAR, $\mu \mathrm{mol} \mathrm{m}^{-2} \mathrm{~d}^{-1}$ ), relative humidity (\%), vapor pressure deficit (VPD, kPa), light use efficiency (LUE, gC $\mu \mathrm{mol} P \mathrm{PAR}^{-1}$ ), enhanced vegetation index (EVI), normalized difference vegetation index (NDVI), land surface temperature (LST, ${ }^{\circ} \mathrm{C}$ ), gross primary production estimated by eddy covariance (GPPEC, $\mathrm{gC} \mathrm{m}^{-2} \mathrm{~d}^{-1}$ ), gross primary production estimated by TG model (GPPTG, $\mathrm{gC} \mathrm{m}^{-2} \mathrm{~d}^{-1}$ ) and gross primary production estimated by VI model (GPPVI, $\mathrm{gC}^{-2} \mathrm{~d}^{-1}$ ) in the AmazonCerrado transitional forest.

\begin{tabular}{cccc}
\hline Variable & Annual & Dry & Wet \\
\hline Ppt & 2079.7 & 76.0 & 2003.7 \\
Temp. & $24.8 \pm 0.3$ & $24.6 \pm 0.3$ & $24.9 \pm 0.2$ \\
PAR & $406.1 \pm 21.1$ & $457.3 \pm 14.5$ & $367.8 \pm 26.1$ \\
UR & $76.1 \pm 2.2$ & $69.6 \pm 2.6$ & $81.2 \pm 2.0$ \\
DPV & $0.62 \pm 0.05$ & $0.80 \pm 0.06$ & $0.49 \pm 0.06$ \\
LUE & $0.41 \pm 0.03$ & $0.28 \pm 0.02$ & $0.51 \pm 0.04$ \\
EVI & $0.53 \pm 0.02$ & $0.53 \pm 0.01$ & $0.54 \pm 0.03$ \\
NDVI & $0.85 \pm 0.02$ & $0.87 \pm 0.01$ & $0.83 \pm 0.03$ \\
LST & $27.0 \pm 0.6$ & $27.93 \pm 0.45$ & $26.4 \pm 0.7$ \\
GPPEC & $8.0 \pm 0.3$ & $6.96 \pm 0.24$ & $8.8 \pm 0.3$ \\
GPPTG & $8.6 \pm 0.3$ & $8.7 \pm 0.2$ & $8.5 \pm 0.4$ \\
GPPVI & $18.5 \pm 0.4$ & $19.3 \pm 0.4$ & $17.6 \pm 0.5$ \\
\hline
\end{tabular}

The relative humidity was $14 \%$ higher in the wet season due to high precipitation (Table 1 ). There was a lower relative humidity in 2005, which is consistent with the intense drought reported for the region (MARENGO et al., 2008). The VPD followed the reverse pattern of precipitation and was $38 \%$ higher during the dry season (Table 1 ). The variables such as relative humidity and VPD used to characterize spatial and temporal patterns of water stress over larger scales affect GPP estimates (BIUDES et al., 2014b; ROBERTSON et al., 2015).

The light use efficiency (LUE) was $44 \%$ higher in the wet season (Table 1) with a strong positive correlation with the precipitation ( $r=0.68 ; p$-value $<0.05)$ and a negative correlation with PAR ( $r=-0.59$; $p$-value $<0.05)$, but there was no correlation with the air temperature. The importance of precipitation for the LUE has been well documented and observed by Sendall et al. (2009) and Vourlitis et al. (2011) to study the net photosynthetic rate and net exchange system in the same area of study. The negative relationship between PAR and LUE is not conclusive, as there is little evidence that the LUE is affected by radiation (BOARDMAN, 1977).

The monthly average of GPP showed a consistent seasonal trend (Figure 2e) with a positive correlation with the precipitation $(r=0.56$; $p$-value $<0.05)$. The GPP was $21 \%$ higher during the wet season (Table 1 ). The strong direct relationship between water availability, rainfall, leaf water potential and photosynthesis have been well documented in the tropical semi-deciduous forests (MIRANDA et al., 2005; SENDALL et al., 2009; BIUDES et al., 2014a). 


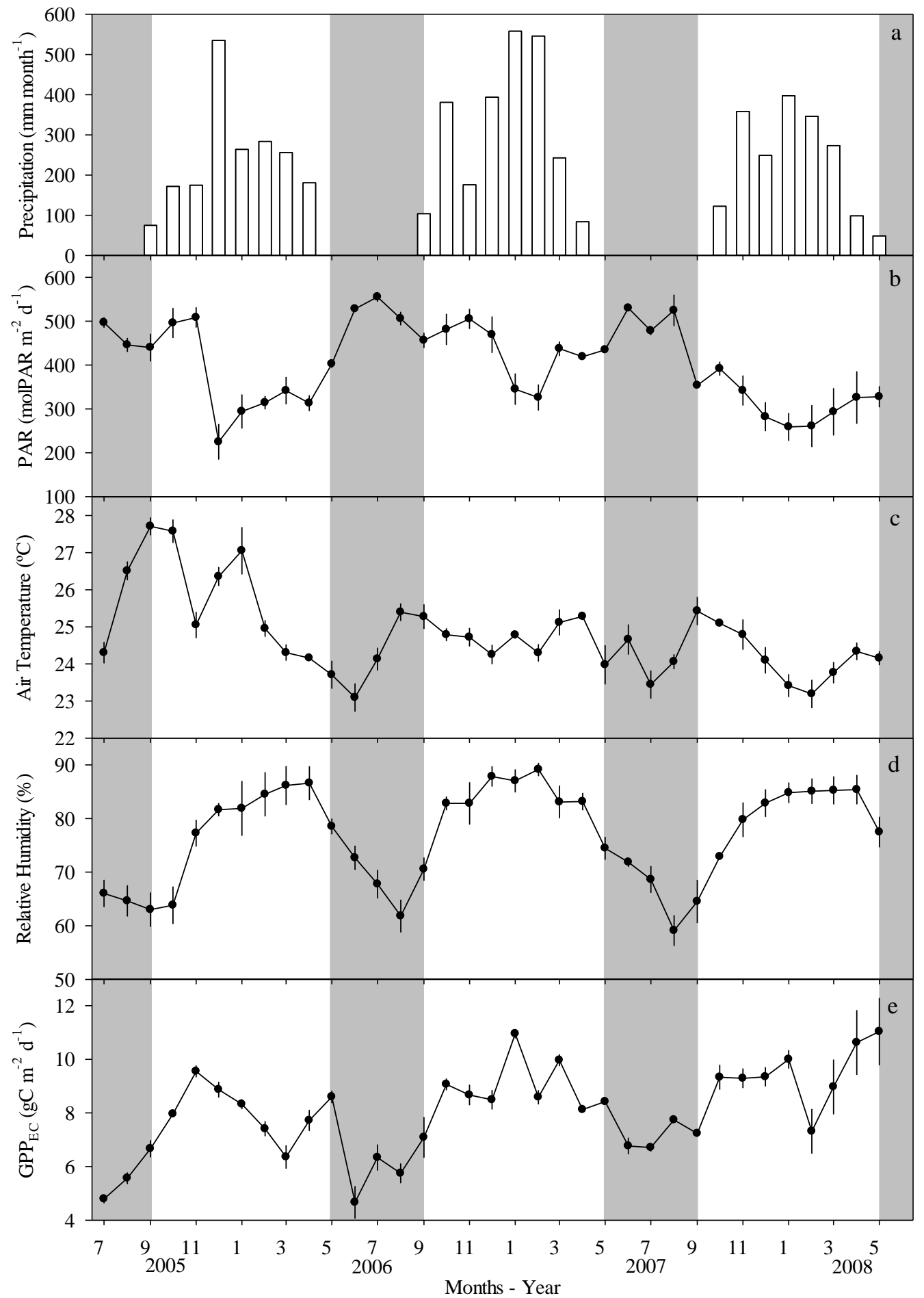

Figure 2 - Total monthly precipitation (a) and mean ( $\pm 95 \%$ confidence interval) monthly photosynthetically active radiation (PAR) (b), air temperature (c), relative humidity (d) and gross primary production measured by eddy covariance (GPP $\mathrm{EC}_{\mathrm{E}}$ (e) in the AmazonCerrado transitional forest. The shaded portion in each figure depicts the dry season at each site. 


\subsection{ANALYSIS OF REMOTE SENSING PRODUCTS}

Seasonal variations of EVI were not consistent, with only a $1 \%$ difference between the wet and dry seasons (Table 1). EVI peaks occurred during the transition period between the dry-wet seasons, especially in November (Figure $3 a)$. The increase of EVI in this period is described as the response to the development of new leaves, the increase of leaf area index (LAI) and the increase of nutrient concentration in leaves that typically occur in the wet season (XIAO et al., 2005). The EVI was only significantly correlated with the air temperature $(r=0.67 ; p$-value $<0.05)$. There was a seasonal variation in the NDVI with an average $4.5 \%$ higher during the dry season (Table 1 ) and minimum value of 0.59 and a maximum of 0.92 (Figure $3 \mathrm{~b}$ ). The NDVI had no correlation with any micrometeorological variable.

Seasonal variations in LST values were consistent over the years, averaging $5 \%$ higher during the dry season with peaks in the dry-wet transition period (Table 1; Figure 3c). The maximum LST was found in 2005, which confirms the values found for the air temperature measured in micrometeorological tower. The LST was negatively correlated with rainfall $(r=-$ $0.75 ; p$-value $<0.01)$ and positively correlated with the VPD ( $r=0.61 ; p$-value $<0.05)$.

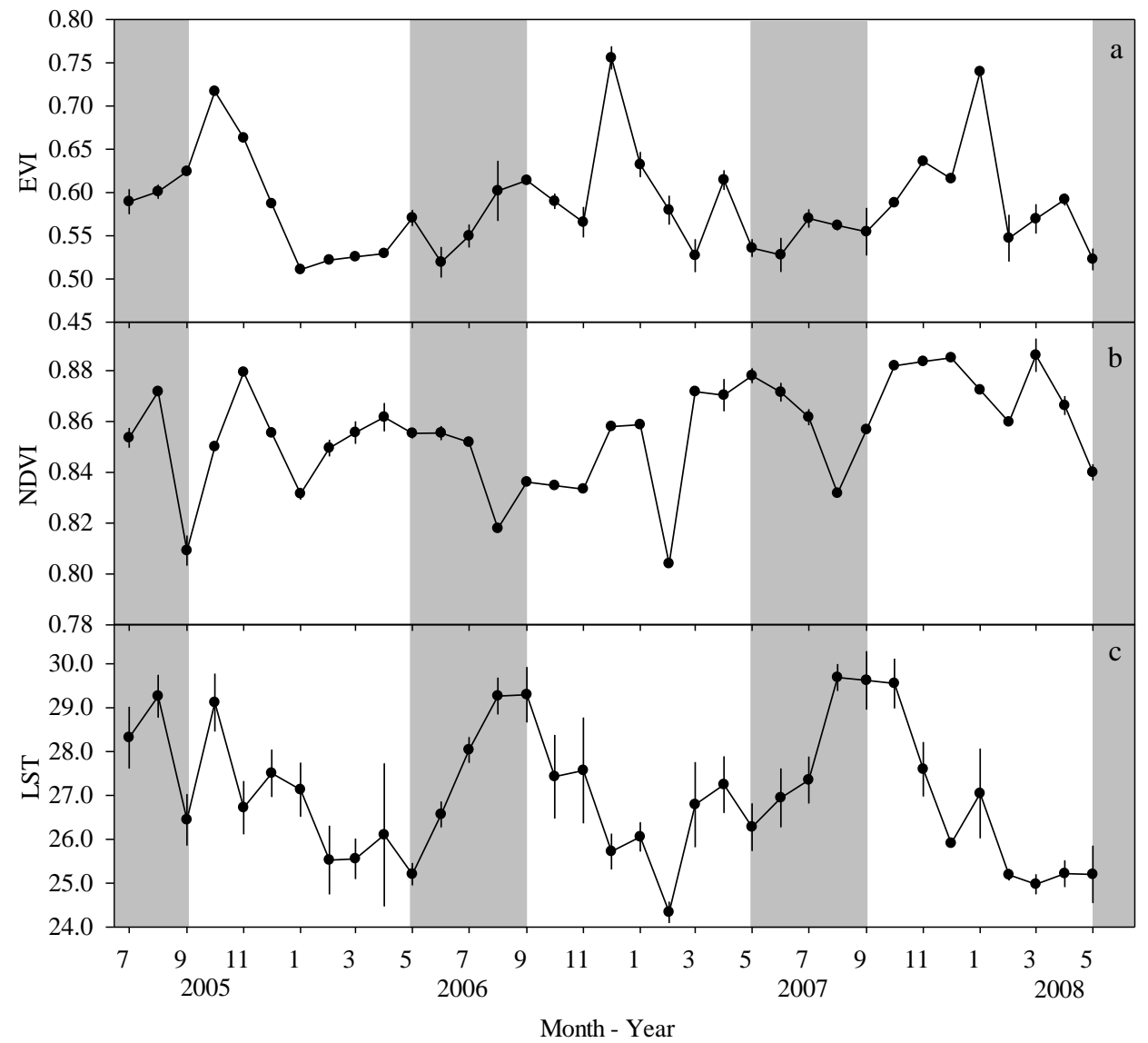

Figure 3 - Mean ( $\pm 95 \%$ confidence interval) enhanced vegetation index (EVI) (a), normalized difference vegetation index (NDVI) (b), land surface temperature (LST) (c) in the Amazon-Cerrado transitional forest. The shaded portion in each figure depicts the dry season at each site. 


\subsection{ANALYSIS OF THE PERFORMANCE OF THE GPP ESTIMATION MODELS}

The GPP estimated by the temperature and greenness model (GPPTG) had no correlation with LST and the DPV. There was no correlation between the GPPTG $_{\mathrm{T}}$ and the GPP measured in the tower (GPPEC; $r=-0.15$ ) and presented coefficient Willmott (d) equal to 0.37 , MAE equal to $0.91 \mathrm{gC} \mathrm{m}^{-2} 8 \mathrm{~d}^{-1}$ and RMSE equal to $2.46 \mathrm{gC} \mathrm{m}^{-2} 8 \mathrm{~d}^{-1}$. The GPPTG was on average $7 \%$ higher than the GPPEC throughout the year, $25 \%$ higher in the dry season and $3.5 \%$ lower in the wet season (Table 1; Figure 4).

The TG model was developed to estimate GPP as a function of surface temperature and water stress (WU et al., 2010), which allows monitoring the physiological aspects of vegetation by incorporating EVI and LST, once GPP could be affected by photosynthetic activity, radiation and climatic variables (SIMS et al., 2008). Although the GPPTG had no correlation with LST and DPV, the GPPTG had positive correlation with PAR $(r=0.72 ; p$-value $<0.01)$.

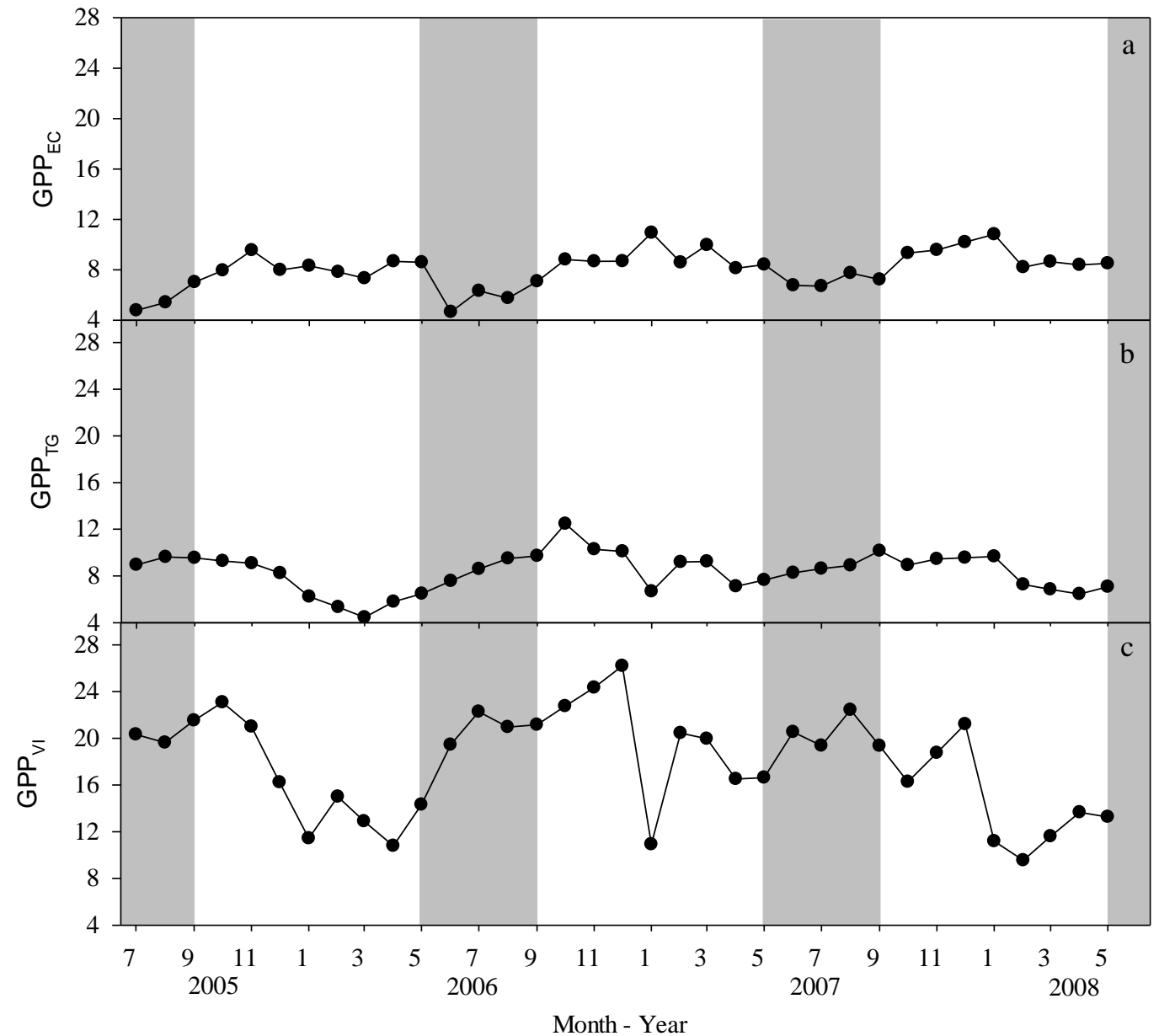

Figure 4 - Mean monthly gross primary production measured by eddy covariance $\left(\mathrm{GPP}_{\mathrm{EC}}\right)$ and estimated by temperature and greenness model (GPPTG) and vegetation index model (GPPVI) in the Amazon-Cerrado transitional forest. The shaded portion in each figure depicts the dry season at each site. 
The lack of correlation between $\mathrm{GPP}_{\mathrm{EC}}$ and GPPTG was due to lack of synchronism between the GPPEC with EVI and LST. The time series of EVI was delayed by 2 months with $\operatorname{GPP}_{\mathrm{EC}}(r=0.44$; $\mathrm{p}$-value $<0.01)$. However, the positive relationship of GPPEC and EVI of tropical forests is well documented and expected, since the EVI dynamics is related to the forest canopy cover dynamics (XIAO et al., 2005). Thus, the spectral reflectance is positively correlated with LAI, concentration of photosynthetic pigments and nutrients in the leaf (ASNER and MARTIN, 2008). LST has little difference with the air temperature in forest regions, but this difference is greater in regions with sparse vegetation (SIMS et al., 2008). As the average daily air temperature does not vary during the year, the TG model also presented limitation to respond to changes in LUE throughout the year.

The model VI estimates the GPP exclusively using satellite data. However, the EVI $(r=0.06)$ and NDVI $(r=0.16)$ had no significant correlation with the GPPEC. The GPPVI had low negative correlation with GPPEC $(r=-0.27)$, but was not significant, and Willmott coefficient (d) was equal to 0.11 , MAE was $10.4 \mathrm{gC} \mathrm{m}^{-2} 8 \mathrm{~d}^{-1}$ and RMSE was $12.1 \mathrm{gC} \mathrm{m}^{-2} 8 \mathrm{~d}^{-1}$. The GPPVI was on average $129 \%$ higher than the GPP measured in the tower throughout the year, $178 \%$ and $100 \%$ higher in the dry and wet seasons, respectively (Table 1; Figure 4).

The use of VI model has different results according to the type of vegetation and water conditions. The VI model had good potential application in deciduous forests (WU et al., 2010), but not in mixed forests and thickets due to the complexity of physiological responses of each species, which are mixed within a single pixel (GEBREMICHAEL and BARROS, 2006). According to Wu et al. (2010), this method works well in homogeneous ecosystems such as agricultural areas. The use of this model has been shown to be problematic in dry environments because the vegetation indices do not show the enough sensitivity to estimate LUE in these conditions (SIMS et al., 2008; ROBERTSON et al., 2015).

\section{CONCLUSIONS}

In this research, two models were used (TG and VI) to estimate GPP in an Amazon-Cerrado transition forest. The combination of EVI and LST was not able to represent the seasonality of LUE, and consequently could not explain the real environmental stress in the study area. The VI model stands out for not depend on any given meteorological input and neither are necessary background information on the type of vegetation (WU et al. 2010). However, no used models were adequate to estimate the GPP.

The results presented here also highlight some of the complexities in validating satellite products. While we pointed out some potential biases in the satellite GPP products, further study over a variety of Brazilian forests is needed to quantitatively assess the TG and VI and other methods in order to improve their accuracy.

\section{ACKNOWLEDGMENTS}

This work was supported in part by the Universidade Federal de Mato Grosso (UFMT), Instituto Federal de Mato Grosso (IFMT), Programa de Pós Graduação em Física Ambiental (PPGFA) IF/UFMT, Coordenação de 
Aperfeiçoamento de Pessoal do Ensino Superior (CAPES) under Grant [number 9750/13-4 and 9768/13-0], Conselho Nacional de Desenvolvimento Científico e Tecnológico (CNPq) under Grant [number 303625/2015-5; Edital Universal/CNPq - 407463/2016-0], Fundação de Amparo à Pesquisa do Estado de Mato Grosso under Grant [PRONEX/FAPEMAT - 823971/2009; Edital Universal/FAPEMAT - 331763/2012; FAPEMAT - PRONEM - 561397/2014].

\section{REFERENCES}

AHLSTRÖM, A.; RAUPACH, M. R.; SCHURGERS, G.; SMITH, B.; ARNETH, A.; JUNG, M.; REICHSTEIN, M.; CANADELL, J. G.; FRIEDLINGSTEIN, P.; JAIN, A. K.; KATO, E.; POULTER, B.; SITCH, S.; STOCKER, B. D.; VIOVY, N.; WANG, Y. P.; WILTSHIRE, A.; ZAEHLE, S.; ZENG, N. The dominant role of semi-arid ecosystems in the trend and variability of the land $\mathrm{CO}_{2}$ sink. Science, v. 348, $\mathrm{n}$. 6237, p. 895-899, 2015.

ANTHONI, P. M.; LAW, B. E.; UNSWORTH, M. H. Carbon and water vapor exchange of an open-canopied ponderosa pine ecosystem. Agricultural and Forest Meteorology, v. 95, p. 151-168, 1999.

ASNER, G. P.; MARTIN, R. E. Spectral and chemical analysis of tropical forests: Scaling from leaf to canopy levels. Remote Sensing of Environment, v. 112, p. 3958-3970, 2008.

BIUDES, M. S.; MACHADO, N. G.; DANELICHEN, V. H. M.; SOUZA, M. C.; VOURLITIS, G. L.; NOGUEIRA, J. S. Ground and remote sensing-based measurements of leaf area index in a transitional forest and seasonal flooded forest in Brazil. International Journal of Biometeorology, v. 58, p. 1181-1193, $2014 a$.

BIUDES, M. S.; SOUZA, M. C.; MACHADO, N. G.; DANELICHEN, V. H. M.; VOURLITIS, G. L.; NOGUEIRA, J. S. Modelling gross primary Production of a tropical semi-deciduous forest in the southern Amazon Basin. International Journal of Remote Sensing, v. 35, n. 4, p. 1540-1562, 2014b.

BIUDES, M. S.; VOURLITIS, G. L.; MACHADO, N. G.; ARRUDA, P. H. Z.; NEVES, G. A. R.; LOBO, F. A.; NEALE, C. M. U.; NOGUEIRA, J. S. Patterns of energy exchange for tropical ecosystems across a climate gradient in Mato Grosso, Brazil. Agricultural and Forest Meteorology, v. 202, p. 112-124, 2015.

BOARDMAN, N. K. Comparative photosynthesis of sun and shade plants, IReview of Plant Physiology, v. 28, p. 355-377, 1977.

CANTY, A.; RIPLEY, B. boot: Bootstrap R (S-Plus) Functions. R package version 1.3-17, 2015.

CHENG, Y. B.; MIDDLETON, E. M.; HILKER, T.; COOPS, N. C.; BLACK, T. A.; KRISHNAN, P. Dynamics of spectral bio-indicators and their correlations with light use efficiency using directional observations at a Douglas-fir forest. Measurement Science and Technology, v. 20, n. 9, p. 1-15, 2009.

DROLET, G. G.; MIDDLETON, E. M.; HUEMMRICH, K. F.; HALL, F. G.; AMIRO, B. D.; BARR, A. G.; BLACK, T. A.; MCCAUGHEY, J. H.; MARGOLIS, H. A. Regional mapping of grss light-use efficiency using MODIS spectral indices. Remote Sensing of Environment, v. 112, n. 6, p. 3064-3078, 2008. 
EFRON, B.; TIBSHIRANI, R. J. An introduction to the bootstrap. Chapman \& Hall, New York. p. 443, 1993.

FALGE, E.; BALDOCCHI, D.; OLSON, R. J.; ANTHONI, P.; AUBINET, M.; BERNHOFER. C.; BURBA, G.; CEULEMANS, R.; CLEMENT, R.; DOLMAN, H.; GRANIER, A.; GROSS, P. ;, GRÜNWALD, T.; HOLLINGER, D.; JENSEN, N.; KATUL, G.; KERONEN, P.; KOWALSKI, A.; LAI, C. T.; LAW, B. E. ; MEYERS, T.; MONCRIEFF, J.; MOORS, E.; MUNGER, J. W.; PILEGAARD, K.; RANNIK, Ü.; REBMANN, C.; SUYKER, A.; TENHUNEN, J.; TUS, K.; VERMA, S.; VESALA, T.; WILSON, K.; WOFSY, S. Gap filling strategies for long terrn energy flux data sets. Agricultural and Forest Meteorology, v. 107, p. 71-77, 2001.

GEBREMICHAEL, M.; BARROS, A. P. Evaluation of MODIS gross primary productivity (GPP) in tropical monsoon regions. Remote Sensing of Environment, v. 100, p. 150-166, 2006.

GITELSON, A. A.; VIÑA, A.; VERMA, S. B.; RUNDQUIST, D. C.; ARKEBAUER, T. J.; KEYDAN, G.; LEAVITT, B.; CIGANDA, V.; BURBA, G. G.; SUYKER, A. E. Relationship between gross primary production and chlorophyll content in crops: Implications for the synoptic monitoring of vegetation productivity. Journal of Geophysical Reserch, v. 111, p. 1984-2012, 2006.

HUETE, A.; LIU, H. Q.; BATCHILY, K.; LEEUWEN, W. A. A comparison of vegetation indices over a global set of TM images for EOS-MODIS. Remote Sensing of Environment, v. 59, n. 3, p. 440-451, 1997.

INOUE, Y.; PEÑUELAS, J.; MIYATA, A.; MANO, M. Normalized difference spectral indices for estimating photosynthetic efficiency and capacity at a canopy scale derived from hyperspectral and $\mathrm{CO}_{2}$ flux measurements in rice. Remote Sensing of Environment, v. 112, p. 156-172, 2008.

JENKINS, J. P.; RICHARDSON, A. D.; BRASWELL, B. H.; OLLINGER, S. V.; HOLLINGER, D. Y.; SMITH, M. L. Refining light-use efficiency calculations over a deciduous forest canopy using simultaneous tower-based carbon flux and radiometric measurements. Agricultural and Forest Meteorology, v. 143, p. 64-79, 2007.

MARENGO, J. A.; NOBRE, C. A.; TOMASELLA, J.; OYAMA, M. D.; de OLIVEIRA, G. S.; de OLIVEIRA, R.; CAMARGO, H.; ALVES, L. M.; BROWN, I. F. The drought of Amazonia in 2005. Journal Climate, v. 21, n. 3, p. 495-516, 2008.

MCMILLEN, R. T. An eddy correlation technique with extended applicability to non-simple terrain. Boundary-Layer Meteorology, v. 43, p. 231-245, 1988.

MIRANDA, E. J.; VOURLITIS, G. L.; PRIANTE-FILHO, N.; PRIANTE, P. C.; CAMPELO JR., J. H.; SULI, G. S.; FRITZEN, C. L.; LOBO, F. A.; SHIRAIWA, S. Seasonal Variation in the Leaf Gas Exchange of Tropical Forest Trees in the Rain Forest-Savanna Transition of the Southern Amazon Basin. Journal of Tropical Ecology, v. 21, p. 451-460, 2005.

NAKAJI, T.; IDE, R.; OGUMA, H.; SAIGUSA, S.; FUJINUMA, Y. Utility of spectral vegetation index for estimation of gross $\mathrm{CO}_{2}$ flux under varied sky conditions. Remote Sensing of Environment, v. 109, p. 274-284, 2007.

PRIANTE-FILHO, N.; VOURTILIS, G. L.; HAYASHI, M. M. S.; NOGUEIRA, J. S.; CAMPELO-JUNIOR, J. H.; NUNES, P. C.; SANCHES, L.; COUTO, E. G.; HOEGER, W.; RAITER, F.; TRIENWEILER, J. L.; MIRANDA, E. J.; PRIANTE, P. C.; FRITZEN, 
C. L.; LACERDA, M.; PEREIRA, L. C.; BIUDES, M. S.; SULI, G. S. ; SHIRAIWA, S. ; PAULO, S. R.; SILVEIRA, M. Comparison of the mass and energy exchange of a pasture and a mature transitional tropical forest of the southern Amazon Basin during a seasonal transition. Global Change Biology, v. 10, p. 863-876, 2004.

ROBERTSON, A. N.; SUYKER, A.; XIAO, X. Modeling gross primary production of maize and soybean croplands using light quality, temperature, water stress, and phenology. Agricultural and Forest Meteorology, v. 213, p. 160-172, 2015.

RUIMY, A.; JARVIS, P. G.; BALDOCCHI, D. D.; SAUGIER, B. $\mathrm{CO}_{2}$ fluxes over plant canopies and solar radiation: a review. Advances in Ecological Research, $v$. 26, p. 1-68, 1995.

RUNNING, S. W.; NEMANI, R. R.; HEINSCH, F. A.; ZHAO, M. S.; REEVES, M.; HASHIMOTO, H. A continuous satellite-derived measure of global terrestrial primary production. Bioscience, v. 54, p. 547-560, 2004.

SAATCHI, S. S.; HARRIS, N. L.; BROWN, S.; LEFSKY, M.; MITCHARD, E. T. A.; SALAS, W.; ZUTTA, B. R.; BUERMANN, W.; LEWIS, S. L.; HAGEN, S.; PETROVA, S.; WHITE, L.; SILMAN, M.; MOREL, A. Benchmark map of forest carbon stocks in tropical regions across three continents. PNAS, v. 108, n. 24, p. 9899-9904, 2011.

SENDALL, M. M.; VOURLITIS, G. L.; LOBO, F. A. Seasonal Variation in the Maximum Rate of Leaf Gas Exchange of Canopy and Understory Tree Species in an Amazonian Semi-Deciduous Forest. Brazilian Journal of Plant Physiology, v. 21, p. 65-74, 2009.

SILVA, B. B.; GALVINCIO, J. D.; MONTENEGRO, S. M. G. L.; MACHADO, C. C. C.; OLIVEIRA, L. M. M.; MOURA, M. S. B. Determinação por sensoriamento remoto da produtividade primária bruta do perímetro irrigado São Gonçalo-PB. Revista Brasileira de Meteorologia, v. 28, n. 1, p. 57-64, 2013.

SIMS, D. A.; RAHMAN, A. F.; CORDOVA, V. D.; EL-MASRI, B. Z.; BALDOCCHI, D. D.; BOLSTAD, P. V.; FLANAGAN, L. B.; GOLDSTEIN, A. H.; HOLLINGER, D. Y.; MISSON, L.; MONSON, R. K.; OECHEL, W. C.; SCHMID, H. P.; WOFSY, S. C.; $\mathrm{XU}$, L. A new model of gross primary productivity for North American ecosystems based solely on the enhanced vegetation index and land surface temperature from MODIS. Remote Sensing of Environment, v. 112, p. 1633$1646,2008$.

SOUZA, M. C.; BIUDES, M. S.; DANELICHEN, V. H. M.; MACHADO, N. G.; MUSIS, C. R.; VOURLITIS, G. L.; NOGUEIRA, J. S. Estimation of gross primary production of the Amazon-Cerrado Transitional Forest by remote sensing techniques. Revista Brasileira de Meteorologia, v. 29, n. 1, p. 1-12, 2014.

TURNER, D. P.; RITTS, W. D.; COHEN, W. B.; GOWER, S. T.; RUNNING, S. W.; ZAO, M.; COSTA, M. H.; KIRSCHBAUM, A. A.; HAN, J. M.; SALESKA, S. R.; AHL, D. E. Evaluation of MODIS NPP and GPP products across multiple biomes. Remote Sensing of Environment, v. 102, n. 3-4, p. 282-292, 2006.

VERMOTE, E. F.; KOTCHENOVA, S. Atmospheric correction for the monitoring of land surfaces. Journal of Geophysical Research-Atmospheres, v. 113, n. D23, p. D23S90, 2008. 
VILANI, M. T.; SANCHES, L.; NOGUEIRA, J. S.; PRIANTE FILHO, N. Sazonalidade da radiação, temperatura e umidade em uma floresta de transição AmazôniaCerrado. Revista Brasileira de Meteorologia, v. 21, n. 3b, p. 331 343, 2006.

VOURLITIS, G. L.; LOBO, F. A.; ZEILHOFER, P.; NOGUEIRA, J. S. Temporal patterns of net $\mathrm{CO}_{2}$ exchange for a tropical semideciduous forest of the southern Amazon Basin. Journal of Geophysical Research, v. 116, p. G03029, 2011.

VOURLITIS, G. L.; NOGUEIRA, J. S.; LOBO, F. A.; PINTO JR., O. B. Variations in evapotranspiration and climate for an Amazonian semi-deciduous forest over seasonal, annual, and El Niño cycles. International Journal of Biometeorology, $\mathrm{v}$. 59, p. 217-230, 2014.

WANG, Z.; XIAO, X.; YAN, X. Modeling gross primary production of maize cropland and degraded grassland in northeastern China. Agricultural and Forest Meteorology, v. 150, p. 1160-1167, 2010.

WEBB, E. K.; PEARMAN, G. I.; LEUNING, R. Corrections of flux measurements for density effects due water vapor transfer. Quarterly Journal of the Royal Meteorological Society, v. 106, n. 447, p. 85-100, 1980.

WILLMOTT, C. J.; MATSSURA, K. Advantages of the mean absolute error (MAE) over the root mean square error (RMSE) in assessing average model performance. Climate Research, v. 30, p. 79-92, 2005.

WOHLFAHRT, G.; ANFANG, C.; BAHN, M.; HASLWANTER, A.; NEWESELY, C.; SCHMITT, M.; DROSLER, M.; PFADENHAEUR, J.; CERNUSCA, A. Quantifying nighttime ecosystem respiration of a meadow using eddy covariance, chambers and modeling. Agricultural and Forest Meteorology, v. 128, n. 3-4, p. 141-162, 2005.

WU, C.; CHEN, J. M.; HUANG, N. Predicting gross primary production from the enhanced vegetation index and photosynthetically active radiation: evaluation and calibration. Remote Sensing of Environment, v. 115, n. 12, p. 3424-3435, 2011.

WU, C.; MUNGER, J. W.; NIU, Z.; KUANG, D. Comparison of multiple models for estimating gross primary production using MODIS and eddy covariance data in Harvard Forest. Remote Sensing of Environment, v. 114, p. 2925-2939, 2010.

WU, C.; NIU, Z.; TANG, Q.; HUANG, W.; RIVARD, B.; FENG, J. Remote estimation of gross primary production in wheat using chlorophyll-related vegetation indices. Agricultural and Forest Meteorology, v. 149, p. 1015-1021, 2009.

XIAO, X.; HOLlingER, D.; ABER, J.; GOLTZ, M.; DAVIDSON, E. A.; ZHANG, Q.; MOORE III, B. Satellite based modeling of gross primary production in an evergreen needle leaf forest. Remote Sensing of Environment, v. 89, p. 519-534, 2004.

XIAO, X.; ZHANG, Q.; SALESKA, S.; HUTYRA, L.; DE CAMARGO, P.; WOFSY, S.; FROLKING, S.; BOLES, S.; KELLER, M.; MOORE III, B. Satellite-based modeling of gross primary production in a seasonally moist tropical evergreen forest. Remote Sensing of Environment, v. 94, n. 1, p. 105-122, 2005. 